\title{
MIKROFINANSE A OPROCENTOWANIE PRODUKTÓW KREDYTOWYCH KIEROWANYCH DO OSÓB UBOGICH
}

\begin{abstract}
Jest coś zdecydowanie nieprzyzwoitego w zachowaniu zorientowanych na maksymalizację zysku inwestorów wspierajacych instytucje mikrofinansowe, które pobieraja 100-procentowe odsetki od najbiedniejszych na świecie ludzi. Tym bardziej jest to niestosowne [...], że komercyjne instytucje mikrofinansowe słabiej pomagają tym ludziom, niż było to przewidziane w momencie ich utworzenia ${ }^{1}$.
\end{abstract}

\section{WSTĘP}

Istotą aktywności podmiotów mikrofinansowych, czyli pośredników świadczących usługi pożyczkowe, ubezpieczeniowe, lokacyjne i transferowe osobom ubogim i mikroprzedsiębiorcom, doświadczającym skutków wykluczenia z głównego nurtu rynku usług finansowych, jest działanie ukierunkowane na wsparcie procesu przełamywania barier rozwojowych, ograniczających zdolność tych jednostek do poprawy warunków swego życia, wychodzenia ze stanu ubóstwa i ograniczania jego konsekwencji. Historia i teraźniejszość współczesnych mikrofinansów dowodza, że najistotniejszym czynnikiem wspierającym osiaganie wskazanych wyżej celów, obok chęci i zdolności do zmiany swego statusu społeczno-ekonomicznego, staje się dostęp do kredytowych form finansowania dających możliwość zainicjowania i/lub podtrzymywania procesu opartego na samomobilizacji sił i środków pozwalających beneficjentom tych usług finansowych, głównie osobom biednym, aktywnie zmieniać ekonomiczne i społeczne warunki własnego życia. Mikrokredyt, tak jak każda usługa finansowa, posiadać powinien swoją cenę, determinowaną z jednej strony przez niefinansowe funkcje przypisywane tego typu produktom, czy szerzej: mikrofinansom w ogóle, z drugiej - odpowiadającą wyzwaniom formułowanym wobec podmiotu mikrofinansowego, determinowanym przez wymóg stabilności finansowej i trwałości prowadzonej działalności. W tym właśnie punkcie pojawia się pewna sprzeczność (dostrzegana przez teorię i praktykę mikrofinansów) odnoszona do podstaw cenowych mikrofinansowych produktów pożyczkowo-kredy-

1 J. C. Lewis, Microloans Sharks, „Stanford Social Innovation Review” 2008, s. 56. 
towych, wiązana z kwestią poziomu tego parametru ekonomicznego, jego bazy i znaczenia dla stron transakcji mikrofinansowej. Mając na uwadze powyższe, formułuje się cel artykułu, którym jest: określenie i analiza uwarunkowań kształtujących oprocentowanie mikropożyczki zarówno w wymiarze teoretycznym, jak i praktycznym oraz przedstawienie własnych, autorskich refleksji dotyczących powyższej problematyki. Realizacji tak sformułowanego zadania podporządkowano strukturę tej pracy, w której wyodrębniono cztery części.

Część pierwszą poświęcono przybliżeniu istoty mikrofinansów, ze szczególnym uwzględnieniem ich roli w procesie przełamywania barier rozwojowych o charakterze ekonomicznym i społecznym. W część drugiej uwage skupiono na problematyce czynników kształtujących oprocentowanie mikrokredytu oraz dyskusji między instytucjonistami a zwolennikami koncepcji państwa opiekuńczego, jako przedstawicielami dwóch, odmiennych poglądów na poziom omawianego parametru. Trzecia część obejmuje statystyki charakteryzujące praktykę oprocentowania mikrokredytów. W części czwartej zawarto opinie i wnioski autora formułowane w pełnej zgodzie z poglądem, że „cena produktów mikropożyczkowych stanowi krytyczny komponent w procesie osiagania subtelnej równowagi pomiędzy stabilnością finansową a społeczna odpowiedzialnością mikrofinansów"2.

\section{ISTOTA MIKROFINANSÓW - ZARYS PROBLEMATYKI}

Odpowiedź na pytanie, czym są mikrofinanse, opierać się może na określeniu wielorakich ról im przypisywanych oraz porównaniu oczekiwań, jakie wobec mikrofinansów formułują ich interesariusze, z praktycznym poziomem osiaganiu tych celów.

Biorac pod uwagę terminologiczne podejściu do mikrofinansów, przytoczyć można różne ich charakterystyki ${ }^{3}$. Dla przykładu Adrian Gonzalez i Richard Rosenberg ${ }^{4}$ postrzegają mikrofinanse jako usługi finansowe dla osób ubogich, oferowane przez podmioty udzielajace niewielkich kredytów, często niezabezpieczonych, kierowanych do ich odbiorców na zasadach odpowiedzialności grupowej, zastępującej tradycyjną zdolność kredytowa, a potwierdzającej gotowość oraz zdolność do terminowego i sumiennego wywiązywania się ze zobowiązań, gwarantująca zarazem możliwość ubiegania się o kolejną pożyczkę. Jacek Adamek ${ }^{5}$ wskazuje, że „poprzez mikrofinanse rozumieć należy świadczenie szerokiego spektrum usług finansowych kierowanych do ludzi biednych i mikroprzedsiębiorstw, umożliwiajaccych im podniesienie poziomu swoich do-

2 C. Mcloughlin, Impact of Microcredit Interest Rates on the Poor: Helpdesk Research Report, GSD RC 2013, s. 3.

${ }^{3}$ Zob. np. A. Alińska, Instytucje mikrofinansowe w lokalnym rozwoju społeczno-gospodarczym, Monografie i Opracowania 558, Szkoła Główna Handlowa w Warszawie, Warszawa 2008, s. 155 i n.

${ }^{4}$ A. Gonzalez, R. Rosenberg, The State of Microfinance-Outreach Profitability and Poverty, Microfinance GateWay 2006, s. 1.

5 J. Adamek, Mikrofinanse islamskie - założenia, produkty, praktyka, CeDeWu, Warszawa 2010, s. 25. 
chodów, a przez to poprawę warunków życia wykorzystujących te usługi i ich rodzin”.

Podczas analizy zadań przypisywanych mikrofinansom warto wspomnieć o czynnikach charakteryzujących przestrzeń, w której przychodzi im realizować swe zadania. Przestrzeń ta może być charakteryzowana przez trzy wyznaczniki: uwarunkowania przepływu kapitału pomiędzy bogatą a biedna częścią społeczeństwa, skalę ubóstwa i ekonomiczno-społeczny obraz życia beneficjentów usług mikrofinansowych ${ }^{6}$. Zdaniem autora elementy te należy traktować jako ramy kształtujace praktykę mikrofinansów, opisywaną przez operacyjny charakter podmiotów mikrofinansowych i ich produktów, oraz postrzegać je przez pryzmat wyzwań formułowanych wobec mikrofinansów, odnoszonych zarówno do kwestii ekonomicznych, jak i społecznych z nimi łączonych.

Z kolei wśród zadań o charakterze ekonomicznym wskazuje się, że istota mikrofinansów jest ograniczanie zjawiska wykluczenia finansowego, ułatwienie dostępu do zasobów pieniężnych, pobudzanie przedsiębiorczości, tworzenie podstaw do gromadzenia i pomnażania dodatkowych oszczędności, a więc kształtowanie poczucia bezpieczeństwa i stabilizacji ekonomicznej, ze wszystkimi konsekwencjami tego stanu. Z drugiej strony, mikrofinanse stają się narzędziem osiagania celów społecznych, skupionych nie tylko na bezpośrednim beneficjencie usług mikrofinansowych, lecz także na grupie społecznej, w której on funkcjonuje. Efekty te dotycza np.: zmiany jego postaw wobec pojawiających się problemów, zmiany sposobu interpretacji i rozumienia otaczającej go rzeczywistości, zmiany zachowań i relacji między jednostkami tworzacymi daną zbiorowość oraz między tymi zbiorowościami? ${ }^{7}$.

W próbach opisu istoty mikrofinansów w świetle porównań czynionych pomiędzy ich deklarowanymi celami a praktycznym poziomem ich realizacji wskazuje się na brak jednoznaczności opinii na temat rzeczywistej skuteczności i efektywności wykorzystania tego narzędzia w walce z ubóstwem na świecie. Dowodem na tę tezę mogą być choćby tytuły opracowań naukowych wiązanych z ocena mikrofinansów, np.: Why Doesn't Microfinance Work? The Destructive Rise of Local Neoliberalism ${ }^{8}$ czy From Exclusion to Inclusion through Microfinance ${ }^{9}$. Wspomniane wyżej kontrowersje odnoszą się zarówno do całościowych ocen formułowanych dla samej koncepcji mikrofinansów i ich praktyki, jak i do szczegółowych zagadnień, łacznych np. z opiniami na temat wsparcia walki z nierównością płci czy też poglądami na temat oprocentowania mikrokredytów ${ }^{10}$. Właśnie to drugie zagadnienie znajdzie swoje rozwinięcie w kolejnych częściach tej pracy.

${ }^{6}$ Szerzej na ten temat w: J. Adamek, Idea i praktyka mikrofinansów-uwagi krytyczne, „Ruch Prawniczy, Ekonomiczny i Socjologiczny” 75, 2013, z. 2, s. 152-156, oraz P. Pluskota, Mikrofinanse w ograniczaniu niedoskonałości rynków kredytowych, CeDeWu, Warszawa 2013, s. 22-28.

${ }^{7}$ J. Adamek, Idea i praktyka mikrofinansów..., s. 156.

${ }^{8}$ M. Bateman, Why Doesn't Microfinance Work? The Destructive Rise of Local Neoliberalism, Zed Books, New York 2010.

${ }^{9}$ From Exclusion to Inclusion Through Microfinance Report 1 - Social and Financial Exclusion Map, MFC 2007.

${ }^{10}$ W latach 1980-2010 przeprowadzono ponad 150 studiów nad efektami łączonymi z aktywnością mikrofinansową: 123 potwierdziły pozytywny wpływ tej formy pośrednictwa finansowego, 


\section{CZYNNIKI KSZTAETUJĄCE OPROCENTOWANIE MIKROKREDYTÓW}

Dyskusja nad poziomem stopy procentowej oraz czynnikami determinującymi wielkość tego parametru jest polem ścierania się wielu koncepcji wiązanych z problemem kształtowania dostępności mikrokredytów, rozpatrywanych w świetle:

- zasadności określonego poziomu oprocentowania mikrofinansowych transakcji kredytowych,

- ekonomiki tych usług, czy też

- etyczno-moralnych dylematów oprocentowania kredytów dla ubogich oraz społecznej roli mikrofinansów.

W kwestii uzasadnionego poziomu oprocentowania mikrokredytów warto zwrócić uwagę na zróżnicowanie ujęć tego problemu, konstruowanych na odmiennych fundamentach, na których opiera się (lub opierać się może) stopa procentowa. Ujęcia te wykorzystują: argumentację moralno-etyczną (podejście deontologiczne), ocenę jej wpływu na sytuację finansową biorcy (podejście konsekwencjonistyczne), ocenę popytu na mikrokredyt (podejście rynkowe), kwestie proceduralne, wiązane z jej ustalaniem (podejście proceduralne). Istotę tych ujęć zaprezentowano w tabeli 1.

Teoria i praktyka mikrofinansów są polem ścierania się dwóch, głównych spojrzeń na stopę procentową mikrokredytów, łączonych z poglądami zwolenników tzw. państwa opiekuńczego i instytucjonalistów. Poglądy te lokują dyskusję na temat uzasadnionego poziomu stopy procentowej w przestrzeni ograniczanej z jednej strony koniecznością ochrony interesu konsumenta, z drugiej zaś - wymogiem trwałości i stabilności działania pośrednika mikrofinansowego. Mianowicie, stronnicy państwa opiekuńczego, a wśród nich najważniejszy przedstawiciel tego nurtu, ojciec współczesnych mikrofinansów - Muhammad Yunus, wychodzą z założenia, że dostęp do tanich usług kredytowych jest czynnikiem wspierajacym społeczno-socjalny wymiar efektów łączonych z mikrofinansami. Wyrażają oni przekonanie, że uzasadniony poziom stopy procentowej winien być rozpatrywany z punktu widzenia pomocy ludziom ubogim, nie zaś jako parametr poprawiający kondycję finansową kredytodawcy, wspierający osiaganie jego celów biznesowych ${ }^{11}$.

Typowym przykładem zastosowania założeń tego nurtu, spajającym pożądany wymiar oprocentowania mikrokredytu z rynkową ceną funduszy wykorzystywanych przez podmiot mikrofinansowy, jest metodyka opracowana przez Yunusa. Autor ten wskazuje, że maksymalna różnica między stopa procentowa transakcji mikrofinansowej a rynkowym kosztem funduszy, finansujących taką działalność, nie powinna być większa niż $10 \%{ }^{12}$. Stwierdza on także, że programy kredytowe pośredników stosujących taką stopę są

28 ukazało nieznaczace, a 3 - negatywne oddziaływanie. Szerzej w: F. Badecarrats, The Impact of Microfinance: What do We Know?, Microfinance Barometer 2013, Convergences, Paris 2013, s. 8.

${ }^{11}$ Szerzej np. J. Sandberg, Mega-Interest on Microcredit: Are Lenders Exploiting the Poor?, „Journal of Applied Philosophy” 29, 2012, nr 3, s. 171-172.

${ }_{12}$ M. Yunus, Creating a World Without Poverty, Public Affairs, New York 2007, s. 69. 


\section{Tabela 1}

Uzasadniona stopa procentowa mikrokredytu - podejścia

\begin{tabular}{|l|}
\hline Podejście deontologiczne \\
\hline Wywodzi swoje korzenie np. z krytyki oprocentowania odnajdywanej np. w: a) poglądach Arysto- \\
telesa, b) krytyki oprocentowania i/lub lichwy zawartej w przekazie religijnym np. Starego Testa- \\
mentu, Koranu, c) marksistowskiej koncepcji wyzysku czy d) keynesowskiego poglądu, że dla po- \\
zbycia się rentierów stopę procentową można, w ciąu jednego pokolenia, ograniczyć do zera. W po- \\
dejściu tym wysoki poziom stóp procentowych traktowany jest jako wewnętrznie niesprawiedliwy \\
lub potencjalnie szkodliwy, a prawo ograniczające lichwę, funkcjonujące w wielu krajach o różnym \\
poziomie rozwoju gospodarczego, postrzega się przez pryzmat ważnego narzędzia powstrzymu- \\
jącego „chciwość” pożyczkodawcy i chroniącego interes klienta. Krytyka tego podejścia łączy się \\
z faktem, że wprowadzenie prawa ograniczającego maksymalny poziom odsetek jest działaniem \\
nieefektywnym, kierujaccym skupienie pożyczkodawców na nieliczną grupę klientów o wysokim \\
poziomie dochodowości (ograniczenie bazy przychodowej pokrywającej wysokie koszty operacyjne \\
wymusza wyłączenie najbiedniejszych z portfela klientów). Stąd też wyższe i bardziej elastyczne \\
stopy procentowe postrzega się jako czynnik zwiększający sprawiedliwość dystrybucji dochodów. \\
\hline
\end{tabular}

Podejście konsekwencjonistyczne

Opiera się na założeniu oceny godziwości oprocentowania w świetle polepszenia lub pogorszenia sytuacji kredytobiorcy. Opinia na temat uzasadnionego poziomu stopy procentowej budowana jest na podstawie oceny kosztów ponoszonych przez klienta w sytuacji braku instytucji mikrokredytowej. Dlatego więc jeśli ta stopa, pozostając wysoką jest niższa od stóp oferowanych np. przez lichwiarzy, traktowana jest jako uzasadniona, gdyż zwiększa ona korzyści biorcy w porównania do efektów, jakie mogłyby być wiązane z wykorzystaniem kredytu o cenie wyższej. Krytyka tego spojrzenia odnosi się m.in. do braku uzasadnia przyjęcia oprocentowania oferowanego przez np. lichwiarzy, jako benchmarku decydującego o sprawiedliwości stopy oferowanej przez instytucje mikrofinansowa, usprawiedliwiającego np. ciąle wysoki poziom tego parametru będący funkcja np. nieuzasadnionych kosztów administracyjnych czy nieumiejętnego zarządzania.

\section{Podejście rynkowe}

Wykorzystuje założenie, zgodnie z którym poziom terminowego zwrotu pożyczonych środków oraz rolowanie transakcji pożyczkowych wskazuje, że nawet ich wysoką cenę traktuje się jako sprawiedliwa/godziwą. Zgodnie z tą optyką większą wagę przypisuje się samemu dostępowi do kredytu nawet przy jego dużym oprocentowaniu, gdyż jego wykorzystanie następuje w obszarach o wysokim poziomie stóp zwrotu. Krytyka tego podejścia opiera się na podniesieniu argumentu dowolności warunków umowy i możliwości ich kształtowania przez stronę "silniejszą" osłabiającą np. pozycję osób ubogich i/lub wykluczonych, szczególnie na niekonkurencyjnych rynkach usług mikrofinansowych.

\section{Podejście proceduralne}

Jego podstawa jest przekonanie, że uzasadniona stopa procentowa jest funkcją wolnego procesu negocjacji, w których ani kredytodawca, ani dłużnik nie są do niczego przymuszani oraz w żadnym obszarze oszukiwani. Podejście to bazuje na dwóch modelach kształtowania uzasadnionej stopy procentowej. M o d el I - przyjmuje, że przy dobrze zorganizowanym i działającym rynku zasadność stopy procentowej wymaga tylko tego, aby reguły tego rynku były prawidłowo i obiektywnie stosowane wobec wszystkich stron na nim działajacych. Model II - wykorzystuje porównanie poziomu stopy procentowej pomiędzy indywidualnymi kredytobiorcami, kształtowanej na podstawie zestawu informacji wykorzystywanych w procesie ich oceny skoringowej, dajacej możliwość scharakteryzowania przyszłej zdolności do spłaty mikrokredytu kredytu. Krytyka dominującego w tym podejściu Modelu II odnosi się do kwestii doboru kryteriów oceny i wag im przypisywanych - szczególnie w sytuacji gdy część z tych kryteriów postrzeganych jest jako zaburzające poczucie uzasadnienia poziomu stóp procentowych (np. płeć, czynniki etniczne).

Źródło: M. Hudon, Fair Interest Rates when Lending to the Poor, FNRS Research, Solvay Business School 2007, s. 4-5; M. Hudon, J. Sandberg, Towards a Theory of Fair Interest Rates on Microcredit, Centre Emile Bernheim, Solvay Business School, CEBWorking Paper No 11/019 2011, s. 7-23. 
programami zorientowanymi na ubóstwo - zaliczając zarazem takie podmioty do tzw. strefy zielonej. Yunus wyróżnia także strefę żółtą i czerwona, w których to wskazana powyżej różnica jest odpowiednio $\leq 15 \%$ i $>$ od $15 \%$. Podmioty mikrofinansowe mieszczące się w strefie czerwonej to $-\mathrm{w}$ jego opinii instytucje lichwiarskie, zorientowane na pomnażanie swych zysków, których głównym celem jest maksymalizacja korzyści finansowych akcjonariuszy ${ }^{13}$.

Oczywiście zaproponowana metodyka spotkała się z krytyka. W ramach tych recenzji wskazuje się m.in., że:

- trzy czwarte instytucji mikrofinansowych działajacych na świecie trafia do strefy czerwonej, liczba ta winna być tłumaczona przez poziom kosztów operacyjnych ponoszonych przez pośredników mikrofinansowych, które to koszty stanowią ok. $62 \%$ wszystkich wydatków pokrywanych przez stopę procentowa, a nie realizowane zyski,

- nie ma dowodów, aby podmioty mikrofinansowe mieszczące się w dowolnej strefie osiagały wyjątkowo wysokie dochody,

- większość podmiotów mikrofinansowych o niskim poziomie wartości jednostkowych kredytów (obsługujących najbiedniejszych klientów) zakwalifikowano do strefy czerwonej,

- organizacje non profit oraz NGO prowadzące aktywność mikrofinansową częściej trafiają do strefy czerwonej niż mikrokredytodawcy komercyjni ${ }^{14}$.

Oceny zaprezentowanej wyżej metodyki - łączącej w założeniu Yunusa społeczno-ekonomiczny interes mikrokredytobiorcy i dawcy - wpisują się w krytykę poglądów zwolenników koncepcji państwa opiekuńczego, głoszoną z kolei przez instytucjonalistów, podporządkowujących postrzeganie uzasadnionego poziomu stopy procentowej mikrokredytu przez pryzmat twierdzenia, że dostęp do kredytu jest ważniejszy niż jego cena. Optyka ta opiera się na krytyce niskich, często subsydiowanych cen mikrokredytów, traktowanych jako: instrument paradoksalnie obniżajacych dostępność usług finansowych dla najbardziej potrzebujacych, narzędzie ograniczające zdolność do rozwoju konkurencyjnej infrastruktury finansowej oraz czynnik, który dysfunkcyjnie wpływa na zachowania kredytobiorców. Wśród pozostałych argumentów popierających spojrzenie instytucjonalistów na uzasadniony poziom stopy procentowej mikrokredytów znajdują się twierdzenia o:

- konieczności zapewnienia stabilności i trwałości działania podmiotu mikrofinansowego, gwarantowanych adekwatną do tych wyzwań ceną kredytu,

- wysokim poziomie rentowności przedsięwzięć gospodarczych wspieranych mikrokredytem, pozwalającym na spłatę długu nawet o wysokiej cenie, czy też

- konkurencyjności tych cen wobec oferty cenowej nieformalnych kredytodawców.

Przedstawione powyżej poglądy oparte są na odmiennych przesłankach ekonomicznych, moralno-etycznych i społecznych. Paradoksalnie, w opinii

13 Ibidem, s. 69.

14 A. Gonzalez, Analizing Microcredit Interest Rates. A Review of the Methodology Proposed by Muhammed Yunus, MIX Data Brief No. 4, MIX 2010, s. 1-2. 
swoich zwolenników, są jedyną optyką pozwalającą w pełni osiagać cele przypisane aktywności mikrofinansowej, wywodzące się z jej korzeni, tj. walki z ubóstwem, wykluczeniem finansowym i społecznym oraz wszystkimi konsekwencjami tych stanów. Podejścia te stają się zarazem czynnikiem kształtującym przyjętą i realizowaną filozofię działania wszystkich stron zainteresowanych rozwojem mikrofinansów oraz determinujacym priorytety i imperatywy wiązane z postrzeganiem istoty mikrokredytów czy szerzej - omawianej tu formy pośrednictwa finansowego.

\section{OPROCENTOWANIE MIKROKREDYTÓW - OBRAZ STATYSTYCZNY}

W przestrzeni publicznej funkcjonuje stereotypowa opinia na temat kwestii oprocentowania mikrokredytów. Wskazuje się w niej na bardzo wysoki, wręcz lichwiarski poziom oferowanych stóp procentowych, a za tym także dużą dochodowość tych produktów, oraz podnosi się kwestię nieetycznego zachowania instytucji mikrofinansowych budujących swą pozycję ekonomiczno-finansową na wyzysku ludzi ubogich zmuszanych do ponoszenia wysokich kosztów finansowania zwrotnego opartego na mikropożyczkach. Wydaje się, że tego rodzaju sądy, biorąc pod uwagę analizę materiału statystycznego ${ }^{15}$, sa dyskusyjne i budowane często na podstawie niereprezentatywnych przypadków, a także rzucają niekorzystne światło na problematykę uzasadnionej stopy procentowej mikrokredytu. Warto w tym miejscu przytoczyć kilka informacji charakteryzujących ten obszar aktywności mikrofinansowej ${ }^{16}$.

Poziom dochodów odsetkowych z transakcji kredytowych oferowanych przez instytucje mikrofinansowe na świecie jest bardzo zróżnicowany, przy czym 95\% tych jednostek wykazuje dochody odsetkowe na poziomie niższym niż 70\%, 75\% podmiotów osiaga dochody odsetkowe niższe niż 40\%, przy średniej dla całej populacji w roku 2011 wynoszącej 27\% rocznie. Niejednorodność ta obserwowana jest także w przekroju:

- regionalnym (na co wpływ ma np.: poziom rozwoju rynku finansowego, wartość ponoszonych kosztów operacyjnych, poziom komercjalizacji aktywności mikrofinansowej),

- orientacji biznesowej kredytodawcy (podmioty for profit wykazują wyższy, średnio o 1,7\%, poziom tych dochodów w stosunku do jednostek non pro$f(t)$,

15 Autor odnosi się tu do dwóch podstawowych źródeł informacyjnych zawierających szerokoaspektowe analizy oprocentowania mikrokredytów w skali światowej z roku 2009 i 2013. Zob. w: R. Rosenberg, A. Gonzalez, S. Narian, The New Moneylenders: Are the Poor Being Exploited by High Microcredit Interest Rates?, CGAP Occasional Paper No. 15, February 2009; R. Rosenberg et al., Microcredit Interest Rates and Their Determinants 2004-2011, Access to Finance Forum, Reports by CGAP and Its Partners No. 7, June 2013.

${ }_{16}$ Prezentowane poniżej wielkości liczbowe obejmują dochody osiagane przez pośrednika mikrofinansowego z transakcji kredytowej kształtowane przez oprocentowanie długu, opłaty i prowizje, odniesione do średniej, rocznej wartości jego portfela kredytowego. 
- poziomu regulacji rynku mikrokredytów (dochody te na regulowanych rynkach, utożsamianych z licencjonowaniem aktywności mikrofinansowej i objęciem jej krajowym nadzorem ostrożnościowym, są średnio niższe o 7-8\% w stosunku do dochodów osiaganych przez podmioty działajace na rynkach nieregulowanych).

Obserwuje się zmianę struktury czynników determinujących poziom dochodów odsetkowych osiaganych przez instytucje mikrofinansowe (zob. wykres 1).

Wzrost strat na pożyczkach i kredytach (determinowany zachowaniami na rynku indyjskim - casusy Andhra Pradesh i meksykański) oraz kosztów finansowych działania tych podmiotów (zwiększenie wykorzystania komercyjnych źródeł finansowania działalności) rekompensowany jest spadkiem kosztów operacyjnych (wynikającym ze zwiększenia efektywności operacyjnej, obniżenia kosztów transakcyjnych i wykorzystania efektów krzywej uczenia się) oraz obniżeniem wartości zysku zawartego w cenie mikrokredytu. Przedstawione na wykresie 1 dane, zdaniem autora, w sposób bezpośredni moga zaprzeczyć obiegowej opinii o nadmiernej dochodowości instytucji mikrofinansowych, determinowanej wysokim poziomem dochodów odsetkowych, a w nich kwotą realizowanych zysków.

\section{Wykres 1}

Średnie dochody odsetkowe z mikrokredytów na świecie

[elementy składowe w \%, wartości zaokrąlone]

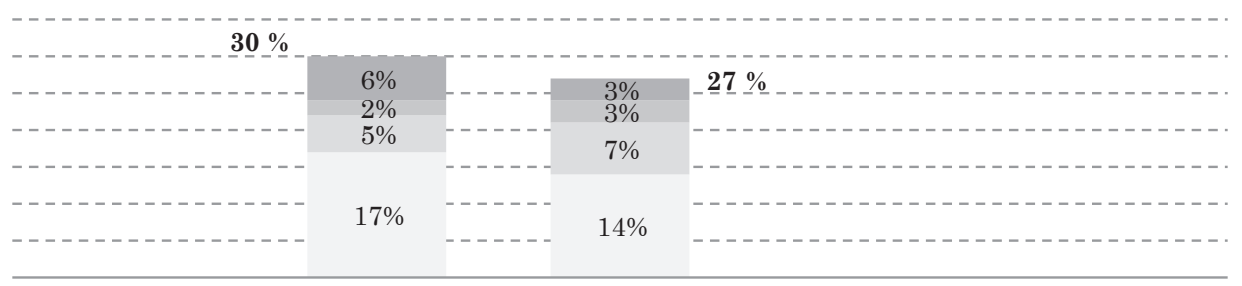

Stopa procentowa Stopa procentowa

- składowe 2004 r. - składowe 2011 r.

Koszty operacyjne $\quad$ Koszty finansowe $\quad$ Straty na pożyczkach $\square$ Zysk

Źródło: R. Rosenberg et al., op. cit., s. 21.

Oferta cenowa transakcji kredytowych pośredników mikrofinansowych, w swym wymiarze światowym, zwykle droższa od propozycji cenowych banków komercyjnych jest ciagle dużo tańsza od oferty pośredników nieformalnych, w tym lichwiarzy. Dysproporcje te widać szczególnie na rynkach krajów rozwijających się (zob. tab. 2). 
Tabela 2

Stopy procentowe w krajach rozwijajacych się

\begin{tabular}{|l|c|c|c|}
\hline \multicolumn{1}{|c|}{ Państwo } & $\begin{array}{c}\text { Banki } \\
\text { komercyjne }\end{array}$ & $\begin{array}{c}\text { Podmioty } \\
\text { mikrofinansowe }\end{array}$ & $\begin{array}{c}\text { Pośrednicy } \\
\text { nieformalni }\end{array}$ \\
\hline Indonezja & $18 \%$ & $28-63 \%$ & $120-170 \%$ \\
\hline Kambodża & $18 \%$ & $\sim 45 \%$ & $120-180 \%$ \\
\hline Nepal & $11,5-18 \%$ & $18-24 \%$ & $\sim 60-120 \%$ \\
\hline Indie & $12-15 \%$ & $20-40 \%$ & $120 \%$ \\
\hline Filipiny & $24-29 \%$ & $60-80 \%$ & $120 \%$ \\
\hline Bangladesz & $10-13 \%$ & $20-35 \%$ & $180-240 \%$ \\
\hline
\end{tabular}

Źródło: J. Sandberg, op. cit., s. 170.

W podsumowaniach rozważań dotyczących ukazanych powyżej statystyk wskazuje się na trudność jednoznacznej odpowiedzi na pytanie, czy przedstawione $\mathrm{w}$ tym punkcie dane dowodzą tezy o nadmiernym lub uzasadnionym poziomie stóp procentowych (dochodów odsetkowych) mikrofinansowych transakcji kredytowych. Wydaje się, że na sformułowanie tej odpowiedzi ma wpływ optyka postrzegania parametru cenowego produktów mikrofinansowych przyjmowana przez obserwatora. Ważne jest, aby w tym spojrzeniu nie tracić z pola widzenia ani ekonomicznego, ani moralno-etycznego znaczenia ceny dla mikrokredytu i mikrofinansów.

\section{WNIOSKI}

Problem wysokości oprocentowania mikrofinansowych transakcji kredytowych jest zagadnieniem obecnym zarówno w teoretycznej, jak i empirycznej przestrzeni tej formy pośrednictwa finansowego. Dyskusje prowadzone w tym obszarze obejmują kwestie: czynników determinujących ten parametr, jego uzasadnionego poziomu, czy też problematyki wpływu stron transakcji kredytowej i ich otoczenia na poziom stopy procentowej. Poglądy na powyższe zagadnienia stają się pochodna przyjmowanych orientacji postrzegania istoty mikrofinansów, celów im przypisanych oraz środków prowadzących do ich osiagania. Mając świadomość wagi problematyki ceny mikrokredytu dla opisu istoty współczesnych mikrofinansów oraz procesu równoważenia ich społecznej odpowiedzialności ze stabilnością i trwałością finansowa, formułuje się poniższe wnioski.

Historyczna i współczesna koncepcja mikrofinansów były i są odpowiedzią na wyzwania stawiane przed człowiekiem, społeczeństwem i państwem, wiązane z występowaniem zjawisk ubóstwa, wykluczenia finansowego i społecznego oraz konsekwencji, jakie te stany niosą dla tych podmiotów. Fakt ten, zdaniem autora, w sposób bezpośredni wskazuje na społeczny charakter tej formy po- 
średnictwa finansowego, a zatem na prymat społecznej odpowiedzialności mikrofinansów nad ich celami i charakterystyką ekonomiczno-finansowa.

Rozwój mikrofinansów, działających w ich ramach podmiotów oraz oferowanych przez nie produktów, musi być także postrzegany przez pryzmat ekonomiki tego rodzaju aktywności, rozumianej w tym miejscu jako poszukiwanie formuł i narzędzi jej równoważenia finansowego. Wskazuje się przy tym jednoznacznie, że ów proces wcale nie musi opierać się na działaniu o charakterze non profit. W opinii autora, uwzględnienie racjonalnego zysku, jako czynnika definiujaccego poziom osiaganych dochodów odsetkowych z transakcji mikrokredytowej, jest działaniem uzasadnionym zarówno w swoim wymiarze moralno-etycznym, jak i ekonomicznym. Ważne jest jednak, aby pamiętać, że „[...] misja mikrofinansów jest powodowanie zmian w życiu ubogich rodzin oraz walka z plagą biedy, nie zaś tworzenie przez spekulację nowej klasy aktywów" 17 .

dr hab. Jacek Adamek

Profesor Uniwersytetu Ekonomicznego we Wroctawiu

jacek.adamek@ue.wroc.pl

\section{MICROFINANCE VS INTEREST RATES OF CREDIT PRODUCTS ADDRESSED TO LOW INCOME CITIZENS}

\section{Sum mary}

The discussion on the condition of contemporary finance is focused on many issues among which a particular emphasis is put on the access conditions to microfinance services, including interest rates of loans and credit products. The belief that interest rates of credits offered to lowincome borrowers should be 'attractive' to allow them to benefit from loans stands in direct opposition to the concept that interest rates must be calculated at a level that will predominantly ensure continuity and stability of the functioning of a microfinance institution, even in a situation when it is necessary to apply high prices of financial services, frequently exceeding the levels specified for interest rates of credits/loans offered by traditional financial intermediaries. These conflicting views create space for the discussion presented in this article, the objective of which is to identify and analyse the determinants of a microloan interest rate from the theoretical as well as practical dimension, and to present the author's own comments referring to the above subject matter.

${ }^{17}$ J. C. Lewis, op. cit., s. 59. 
Copyright of Journal of Law, Economics and Sociology is the property of Faculty of Law and Administration of Adam Mickiewicz University in Poznan and its content may not be copied or emailed to multiple sites or posted to a listserv without the copyright holder's express written permission. However, users may print, download, or email articles for individual use.

Właścicielem praw autorskich do „Ruchu Prawniczego, Ekonomicznego i Socjologicznego” jest Wydział Prawa i Administracji Uniwersytetu im. Adama Mickiewicza w Poznaniu. Zawartość czasopisma nie może być kopiowana, przesyłana do innych stron internetowych bądź zamieszczana na blogach bez pisemnej zgody wydawcy. Niemniej artykuły można drukować, kopiować lub przesyłać w formie elektronicznej na własny użytek. 